\title{
Spirolide uptake and detoxification by Crassostrea gigas exposed to the toxic dinoflagellate Alexandrium ostenfeldii
}

\author{
Walid Medhioub ${ }^{a, b, c}$, Patrick Lassus ${ }^{a, *}$, Philippe Truquet $^{a}$, Michèle Bardouil ${ }^{a}$, Zouher Amzil $^{a}$, \\ Véronique Sechet $^{\mathrm{a}}$, Manoella Sibat ${ }^{\mathrm{a}}$, Philippe Soudant $^{\mathrm{c}}$
}

\author{
a Laboratoire Phycotoxines, IFREMER, Institut Français de Recherche pour l'Exploitation de la Mer, BP21105 \\ 44311 Nantes CEDEX3, France \\ ${ }^{b}$ Laboratoire d'Aquaculture, INSTM, Institut National des Sciences et Technologies de la Mer, Route de Kniss - \\ 5000 Monastir, Tunisie \\ ${ }^{c}$ Université de Bretagne Occidentale - IUEM, LEMAR CNRS UMR 6539, Place Nicolas Copernic, technopôle \\ Brest Iroise - 29280 Plouzané, France
}
*: Corresponding author : Patrick Lassus, Tel.: + 332403741 30., email address : Patrick.Lassus@ifremer.fr ; medhwalid@yahoo.fr ; Philippe.Truquet@ifremer.fr ; Michele.Bardouil@ifremer.fr ; Zouher.Amzil@ifremer.fr ; Veronique.Sechet@ifremer.fr ; Manoella.Sibat@ifremer.fr ; Philippe.Soudant@univ-brest.fr

\section{Abstract:}

Oysters (Crassostrea gigas) were exposed 4 days to cultures of the toxic dinoflagellate Alexandrium ostenfeldii (strain CCMP1773) that produces spirolides belonging to fast acting toxins (FAT) and let depurate for 7 days. During depuration, oysters were either fed the non-toxic algae Isochrysis galbana Tahitian clone ( $T$. Iso) or starved. The objectives of this experiment were to evaluate (i) spirolide uptake and depuration by oysters (ii) spirolide effects on oysters and (iii) oyster recovery according to food supply during depuration.

A. ostenfeldii cells were filtered and ingested by oysters while faeces contained numerous intact cells of the toxic diet. This suggested that ingested cells were not totally digested by oysters. Contents of spirolides (SPX) in digestive gland and remaining tissues during contamination and detoxification periods were measured by liquid chromatography coupled with tandem mass spectrometry (LCMS/MS). Four different SPX analogues (13,19-didesMeC, 13-desMeC, 13-desMeD and trace of SPXD) were detected. The 13,19-didesMeC-SPX dominated in both digestive gland and remaining tissues. After four days exposure, digestive gland (DG) contained $83 \%$ of the total initial spirolide concentration, whereas remaining tissues contained only $17 \%$. During detoxification, spirolide content in DG was lower in fed than in unfed oysters but similar in remaining tissues.

Exposure to $A$. ostenfeldii resulted in an inflammatory response consisting of hemocyte infiltration and diapedesis into the intestinal tract of the oysters. Percentage of active digestive tubules in oysters fed A. ostenfeldii was significantly lower than in control (prior exposition) oysters (36\% and $61 \%$, respectively). At the end of the detoxification period, there was a significant difference in the percentage of active digestive tubules $(P<0.001)$ between fed and unfed oysters. When oysters were 
fed T-Iso following the $A$. ostenfeldii exposure, $80 \%$ of digestive tubules were active, thus revealing a rapid recovery after toxic algae exposure.

Overall, both spirolide detoxification and recovery from their toxic effects are almost complete within 7 days after exposure to spirolide producers. Such information may help to resume faster oyster sales after toxic events involving FAT implying thus more frequent chemical analysis.

\section{Highlights}

Oysters exposed to Alexandrium ostenfeldii cultures accumulate mainly 13.19-didesMeC-SPX. Oyster DG and remaining tissues contained respectively $83 \%$ and $17 \%$ of total SPX after 4 days contamination. Exposure to $A$. ostenfeldii led to haemocytes infiltration and diapedesis (inflammatory effects). Percentage of active digestive tubules was lower in exposed oysters. When nontoxic diet was applied to SPX-contaminated oysters detoxification was almost complete within 7 days.

Keywords: Spirolides ; Alexandrium ostenfeldii ; Contamination ; Depuration ; Crassostrea gigas ; Inflammatory responses 


\section{Introduction}

The marine dinoflagellate Alexandrium ostenfeldii has been identified as the only microorganism producing spirolide toxins (Cembella et al., 2000a and b). This species has been found in Denmark (Moestrup and Hansen, 1988), Scotland (John et al., 2003a), Norway (Balech and Tangen, 1985) and Spain (Fraga and Sanchez, 1985), and it produces either saxitoxin analogues, i.e paralytic shellfish poisoning (PSP) toxins, or spirolide toxins, which belong to cyclic imine group. Some $A$. ostenfeldii strains can produce spirolides and PSP toxins at the same time, as demonstrated in Denmark (Hansen et al., 1992; McKinnon et al., 2004) with local strains.

Compared to other Alexandrium species, relatively little is known to date about the biology and ecology of $A$. ostenfeldii. This may be partly attributed to the fact that it typically occurs at low concentrations of $10^{2}$ to $10^{3}$ cells $\mathrm{L}^{-1}$ in phytoplankton mixed assemblages which already contain other bloom-forming dinoflagellates (Balech and Tangen, 1985; Moestrup and Hansen 1988; John et al., 2003b; Gribble et al., 2005). A. ostenfeldii is known for its capability to behave as a mixotrophic species (Jacobson and Anderson 1996; Gribble et al., 2005) and to produce allelochemical compounds (Hansen et al., 1992; Tillmann et al., 2007).

A. ostenfeldii life cycle includes two types of cysts. Temporary cysts are commonly formed when cells are subjected to stress either in cultures or at field (Østergaard-Jensen and Moestrup 1997; Cembella et al., 2001). Resting cysts are formed in winter and are generally isolated from coastal sediment (MacKenzie et al., 1996b; Bravo et al., 2006).

Like other Alexandrium species, A. ostenfeldii can produce paralytic shellfish toxins (PSTs) (Hansen et al., 1992; MacKenzie et al., 1996b). PST profiles and specific toxicities in culture may vary largely according to strains and localities. It has been noticed that Danish $A$. ostenfeldii strains, predominantly, produce low potency saxitoxin derivatives (Hansen et al., 1992), whereas in New Zealand strains PSP toxicity ranged from 0 to much higher levels (up to $217 \mathrm{pg} \mathrm{STX} \mathrm{eq} \mathrm{cell}{ }^{-1}$ ) than usually observed in cells of other potent Alexandrium species (MacKenzie et al., 1996a,b,c). North Atlantic populations of A. ostenfeldii do not seem to produce PST's at all (Cembella et al., 2000b; Gribble et al., 2005). Instead, spirolides, a recently isolated group of highly potent neurotoxins (Hu et al., 1995; Richard et al., 2000), are commonly found in cultured strains and natural samples (Cembella et al., 2000b; John et al., 2003b; Gribble et al., 2005).

In June 2005, the French Phytoplankton and Phycotoxin monitoring Network (REPHY) revealed the presence of $A$. ostenfeldii for a short period in Arcachon Bay (French S.W coasts). For the first time, spirolides were detected (Amzil et al., 2007) in local oyster digestive glands. When shellfish are contaminated by this toxic microalga at a level giving a positive DSP mouse bioassay, they are no longer harvested and marketed resulting in serious economic losses. Spirolides are 'Fast Acting Toxins' (FAT), causing neurotoxic symptoms and rapid death of laboratory mice when intraperitonially (i.p) injected or administered orally (Hu et al., 1995). However, no adverse effects on humans have been reported so far. Although their toxicity to humans and their mode of action are still under investigation (Gribble et al., 2005), spirolides are known to produce an antagonistic effect at the muscarinic acetylchloline receptor (Richard et al., 2000).

The characterization of the most common spirolides and their des-methyl derivatives from toxic plankton and contaminated shellfish has recently been reported by different authors ( $\mathrm{Hu}$ et al., 2001; Sleno et al., 2004; MacKinnon et al., 2006). Toxicological studies on mice revealed that toxicity of pure 13-des $\mathrm{MeC}$ is much lower when administered by gavage than when i.p injected, with LD 50 of $150 \mu \mathrm{g} \cdot \mathrm{kg}^{-1}$ and 5-8 $\mu \mathrm{g} . \mathrm{kg}^{-1}$, respectively (Munday, 2008). 
Insofar as no regulatory limits have been established for macrocyclic imines (FAO/IOCNWHO report, 2004), no data were available about spirolide bioaccumulation and elimination pathways in shellfish.

The present study investigated (i) the uptake and detoxification of spirolides by oysters, (ii) the impact of non-toxic algal food on detoxification rates, testing the hypothesis that oysters fed $I$. galbana detoxified faster than unfed (control) oysters (iii) the effects of $A$. ostenfeldii experimental exposure on tissue structures and recovery ability of contaminated oysters during depuration.

\section{Materials and Methods}

\subsection{Experimental animals before exposure to A. ostenfeldii}

Triploid oysters, Crassostrea gigas (64.3 $\pm 2.8 \mathrm{~mm}$ mean shell length), were obtained from the IFREMER coastal laboratory located in Bouin (French Atlantic coast). All oysters $(n=108)$ were cleaned from epiphytes and other encrusting organisms. Prior exposure to $A$. ostenfeldii, oysters were acclimatized for 3 days in a raceway filled with seawater at $16{ }^{\circ} \mathrm{C}$ and fed on T.Iso for only one day. Mean of oyster total fresh tissues weight was $6.26 \pm 0.91$ $\mathrm{g} /$ individual $(\mathrm{n}=10)$. The same sample (non exposed control) was used for the histology study.

Eight other oysters were also used for extraction and analysis lipophilic toxins (okadaic acid, pectenotoxins, azaspiracides, yessotoxines, spirolides and gymnodimines).

\subsection{Algal cultures}

The harmful algal species used in this study was the CCMP1773 strain of Alexandrium ostenfeldii (Balech) isolated from Limfjorden (Denmark) and obtained from the Provasoli Guillard National Center for Culture of Marine Phytoplankton. In addition, the non-toxic Tahitian clone of Isochrysis galbana (T. Iso) acclimated in IFREMER laboratory was used as a non-toxic detoxification diet. A. ostenfeldii was grown in 10-liter batch cultures and 100-liter photo-bioreactors using sterile sea water at a salinity of 35 psu supplemented with L1 nutrient enrichment (Guillard and Hargaves, 1993). T. Iso was grown in 10-liter culture vessels filled with seawater previously autoclaved $\left(121^{\circ} \mathrm{C}, 2\right.$ bars, $\left.2 \mathrm{~h}\right)$, filtered seawater through a $0.22 \mu \mathrm{m}$ membrane (Whatman allipore filter) and enriched with Conway medium.

Batch cultures were maintained at $16^{\circ} \mathrm{C}$ under a $12 \mathrm{~h}: 12 \mathrm{~h} \mathrm{~L}: \mathrm{D}$ cycle at $150 \mu$ mole photon $/ \mathrm{m}^{2} / \mathrm{s}$ and was used to inoculated a 100 litre photobioreactor filled with 35 psu sterile seawater prepared as above and enriched with L1 medium (Guillard and Hargraves, 1993). Culture were maintained at $17^{\circ} \mathrm{C}$ under a $16 \mathrm{~h}: 8 \mathrm{~h}(\mathrm{~L}: \mathrm{D})$ cycle and at $170 \mu \mathrm{mole}$ photon $/ \mathrm{m}^{2} / \mathrm{s}$.

T. Iso cultures were harvested for oyster feeding during the exponential phase of growth (days 14).

\subsection{Experimental design for $\boldsymbol{A}$. ostenfedii exposures}

After the 3 days acclimation, 90 oysters were distributed randomly into two raceways filled with 150 I seawater at a salinity of $35 \mathrm{psu}$ and a temperature of $16^{\circ} \mathrm{C}$. The experimental setting was similar to that previously described in Lassus et al. (1999). A 40 I buffer tank placed within the circuit just after the flume outlet contained the heat exchanger and the pumps, ensuring circulation of the water and continuous measurement of chlorophyll with a Turner Design fluorometer equipped with 340-500 nm excitation and $665 \mathrm{~nm}$ emission filters. Toxic and non-toxic micro-algae inputs at the flume inlet were supplied by an Ismatec 
peristaltic micropump with flow rate regulated according to the settings established at the beginning of the experiment. Continuous measurements provided by the fluoremeter were integrated via a $\mathrm{LABVIEW}^{\circledR}$ acquisition and control card and a data-logger connected to a microcomputer.

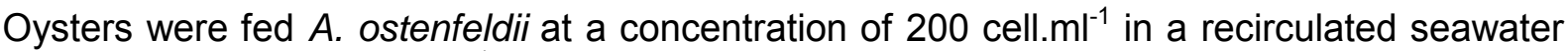
circuit (flow rate of $800 \mathrm{I}^{-\mathrm{h}^{-1}}$ ) for 4 days. Sea water was totally renewed every two days. Following $A$. ostenfeldii exposure, oysters were divided in two groups: 45 oysters were fed T. Iso at 12000 cell. ml $^{-1}$ for 7 days, whereas, another 45 oysters group was not fed (sea water only) during the same period. Faeces and pseudo-faeces were removed every day from each raceway with a pipette and examined to verify the status of the cells using light microscopy.

Oysters samples were collected after 4 days exposure to the toxic dinoflagellate (day 0 ), and during detoxification period, i.e on days 1, 4, and 7. At each sampling time, 8 oysters were removed from the raceway, pooled and processed for spirolide extraction and analysis. Ten oysters were also sampled for the histopathology study after exposure to A. ostenfeldii, and after 7 days detoxification with or without food supply.

\subsection{Extraction and LC-MS/MS analysis of spirolides}

Soft parts of eight oysters were dissected and then divided into two fractions: digestive gland and remaining tissues (including gill, adductor muscle and mantle). These two fractions (which pooled tissues from eight oysters) were drained on a Büchner funnel, weighed, and then frozen at $-80^{\circ} \mathrm{C}$. Tissues were homogenized using Ultra-turrax homogenizer for 5 minutes in a cold environment (ice). Two $\mathrm{g}$ of homogenized digestive gland or remaining tissue were used for lipophilic toxin extraction. Lipophilic toxins were extracted with $3 \mathrm{~mL}$ of methanol/water (95/5). Extracts were then centrifuged at $3000 \mathrm{~g}$ and $4^{\circ} \mathrm{C}$ for $15 \mathrm{~min}$. The pellet was re-extracted 2 more times with $3 \mathrm{~mL}$ of methanol/water (95/5) and centrifuged again. The three supernatants were combined and homogenized. A two $\mathrm{mL}$ sub-sample was ultra-filtered by centrifugation through a $0.2 \mu \mathrm{m}$ membrane (Vivaspin2 ${ }^{\circledR}$ membrane 10000 $\mathrm{KDa}$ PES) at $4000 \mathrm{~g}$ and $4{ }^{\circ} \mathrm{C}$ for 20 minutes. $5 \mu \mathrm{l}$ of the filtrate were injected into the LCMS/MS system. For $A$. ostenfeldii culture, spirolide production and profiles were determined from $10 \mathrm{~mL}$ samples taken from photobioreactor cultures during the exponential phase of growth. Cells were collected by centrifugation $\left(4000 \mathrm{~g}, 10 \mathrm{~min}, 4^{\circ} \mathrm{C}\right)$, resuspended in $1 \mathrm{~mL}$ methanol/water (95/5) and sonicated $20 \mathrm{mn}$ on ice with a Vibra Cell ${ }^{\circledR} 75115$ device. The extracts were collected in $2 \mathrm{~mL}$ eppendorf tubes and then frozen at $-80^{\circ} \mathrm{C}$. Extra-cellular medium of $A$. ostenfeldii culture was extracted according to Amzil et al., 2007 and analysed as described below.

The LC-MS/MS analysis were performed according to Amzil et al, (2007) using a Shimadzu LC-20 AD XR ${ }^{\circledR}$ model coupled with a Q TRAP ${ }^{\circledR}$ mass spectrometer (API 4000). Toxins were eluted in a $3 \mu \mathrm{m}$ hyperclone MOS C8 column (50X2.0 mm, Phenomenex) at $20{ }^{\circ} \mathrm{C}$ with a linear gradient set at $0.2 \mathrm{ml} / \mathrm{min}$. The mobile phase consisted of two components $(A)$ water and (B) acetonitrile/water (95:5), both containing $50 \mathrm{mM}$ formic acid and $2 \mathrm{mM}$ ammonium formate. Analyses were carried out in multiple reaction monitoring (MRM) positive ion mode and the two most intense product ions per compound were selected. Four different spirolides were identified by HPLC-MS in oyster tissues using transition conditions presented in table 1. Spirolides in $A$. ostenfeldii culture and oyster tissues were quantified using calibration curve of 13-desMeC certified standard (NRCC, National Research Council (Canada). Good linear calibration curve $\left(r^{2}=0.9976\right)$ was obtained using 8 spirolide standard solutions $(1.5,3.0,5.0$, 10.0, 15.0, 20.0, 50.0 and $\left.100.0 \mathrm{ng} \cdot \mathrm{mL}^{-1}\right)$. Spirolides analytical pools were performed in triplicate with LC-MS/MS analysis. 


\subsection{Histology}

A 5-mm cross-section was taken from each of the ten oysters sampled for histology, including digestive gland, gills and mantle. The dissected tissues were fixed in Davidson's fixative (Shaw and Battle, 1957) for $48 \mathrm{~h}$. The dehydration steps were performed in increasing ethanol solutions (Ethanol $80 \%$ for $1 \mathrm{~h}$, Ethanol $95 \%$ three times for 2, 2 and $1 \mathrm{~h}$ and Ethanol $100 \%$ three times again for 2, 2 and $1 \mathrm{~h}$ ). Sections were cleared 2 times with Claral, and then embedded in paraffin. After processing, $5 \mu \mathrm{m}$ sections were stained using hematoxylin-eosin. Slides were examined under a light microscope and tissue damaging level was evaluated referring to Haberkorn et al. (2010). Intensity of pathological figures was ranked as stage 0 for absence or very light, stage 1 for moderate and stage 2 for heavy. Results were expressed as mean of stage intensity for ten individuals per treatment.

The thickness of digestive gland tubule was measured. In this study, active and inactive digestive gland tubules were characterized by thickness between $20 \mu \mathrm{m}$ to $30 \mu \mathrm{m}$ and thickness between 10 and $20 \mu \mathrm{m}$, respectively. The percentage of active digestive gland was determined on ten oysters for each treatment. Measurements involved three readings on 70 tubules chosen for each individual oyster using Leica Application Suite 2.8.1. software.

\subsection{Statistical analysis}

Results obtained on digestive gland tubule thickness were compared between treatments after 7 days detoxification using $T$ test. Ratio and percentage were transformed as arcsin(squareroot) before statistical analysis but presented as untransformed data.

Intensity of pathological effects observed by histology was compared statistically using the Pearson chi-square test to assess differences between treatments after detoxification. Significant differences between treatments (with or without feeding) are considered statistically significant at $95 \%$ confidence level.

\section{Results}

\subsection{Toxin profile of Alexandrium ostenfeldii culture}

All spirolide analogues were analysed through three successive injections. Toxin profile of $A$. ostenfeldii during the exponential phase comprised spirolides 13,19-didesMeC, 13-des MeC, 13-desMeD and trace of SPX-D, with 13,19-didesMeC as predominant analogue (Fig 1a). Total toxin content of $A$. ostenfeldii cells was $2.1 \pm 0.1 \mathrm{pg} 13$-desMeC eq. pg cell ${ }^{-1}$ (Table 2 ).

Proportion of spirolide in the extra-cellular medium $A$. ostenfeldii culture was low (1-3\%).

\subsection{Spirolide distribution and profile in oysters following A. ostenfeldii exposure}

Prior exposure to $A$. ostenfeldii, sampled oysters were free from lipophilic toxins (okadaic acid, pectenotoxins, azaspiracides, yessotoxines, spirolides and gymnodimines). This means that toxins were not present above both limits of detection (LOD) and quantification (LOQ) of each toxin. In this study, the LOD and LOQ were determined according to each toxin standard and were summarised in table 3.

After 4 days contamination, toxin content of digestive gland was $567.5 \mu \mathrm{g} 13-\mathrm{desMeC} \mathrm{eq.} \mathrm{kg}^{-}$ ${ }^{1}$ (Fig. 2a), whereas toxin content of remaining tissues was much lower, i.e : $116.2 \mu \mathrm{g} 13$ desMeC eq. $\mathrm{kg}^{-1}$ (Fig. 2b). $83 \%$ of total toxin body concentration was found in digestive gland while only $17 \%$ was found in remaining tissues. After 4 days exposure, toxin profiles in digestive gland and remaining tissues were similar to that of $A$. ostenfeldii (Fig. $1 \mathrm{a}$ and $\mathrm{b}$ ). 
Spirolide 13,19-didesMeC toxin dominated in all organs, and accounted for $72.5 \%$ and 65.5 $\%$ of total toxins respectively in digestive gland and remaining tissues, immediately followed by spirolides 13 -desMeC $(22.5 \%$ and $25 \%$, respectively) and 13-desMeD (4.5\% and 9.5\%, respectively) (Fig. 1 b).

During 7 days detoxification, toxin accumulated in oysters (GD and remaining tissues) decreased rapidly in both T.Iso fed and unfed oysters (Fig. 2 a and b). Total toxin contents of digestive gland after 1, 4 and 7 days were lower in oysters fed T.Iso than in unfed oysters (Fig. 2a) while no differences were observed in remaining tissues (Fig. 2b). After 7 days, DG of fed oysters had lost $92 \%$ of their toxins whereas meantime unfed oysters lost only $80 \%$. Detoxification coefficients were 0.84 day $^{-1}$ in unfed oysters and 0.97 day $^{-1}$ in T.Iso fed oysters (1.15 time faster). Slow detoxification was found in remaining tissues and the final concentration was similar for fed and unfed oysters (Table 4). Whatever the dietary treatments and organs used, most of the detoxification was accomplished within 4 days. Considering individual congeners, detoxification of 13, 19 didesMeC and 13-desMeC was faster than those of 13-desMeD. Less than $10 \%$ of the initial 13,19 didesMeC and 13desMeC contents were left in fed oysters and less than $25 \%$ in unfed oysters (Table 4 ). Detoxification of 13-desMeD was similar in fed and unfed oysters and reached less than $35 \%$ after 7 days of detoxification (Table 4).

At the end of the detoxification period, spirolide analogue concentrations were similar in digestive gland and remaining tissues for the two treatments (with or without feeding) except the higher concentrations of 13,19-didesMeC and 13-desMeC in digestive gland of unfed oyster (Table 4).

\subsection{Histology}

Tubule thickness in digestive gland decreased in all oysters exposed to $A$. ostenfeldii, except one oyster (Fig. 3), and the percentage of active digestive tubules was significantly lower than in control oysters (36\% and $61 \%$, respectively). After 7 days detoxification, percentage of active digestive tubules was significantly higher $(p<0.001 ; n=10 ; t$-test $)$ in oysters fed T. Iso $(77.9 \%)$ than in unfed oysters $(24 \%)$.

High numbers of intact $A$. ostenfeldii cells were observed in intestinal lumen of oysters exposed to A. ostenfeldii (Fig. 4) and in feces (Fig. 5). No A. ostenfeldii cells were observed in digestive tubules. No T.Iso cells were observed intact in any part of the digestive gland.

Observed pathologies consisted mainly in inflammatory responses (Fig.4); aggregation of hemocytes into the connective tissue surrounding the intestine and hemocyte migrations through the intestinal epithelia (diapedesis) (Fig. 4).

Although some damages were observed in control oysters, damages in digestive gland after exposure to $A$. ostenfeldii were significantly more frequent than before exposure (Table 5).

Recovery from these pathological conditions (hemocyte surrounding and diapedesis in intestinal groove and digestive tubules, tubule dilation) was faster in fed oysters than in unfed oysters after 7 days of detoxification. 


\section{Discussion}

\subsection{Spirolide accumulation and detoxification in oysters}

Pacific oyster, Crassostrea gigas, accumulated spirolides within a short time (4 days) when

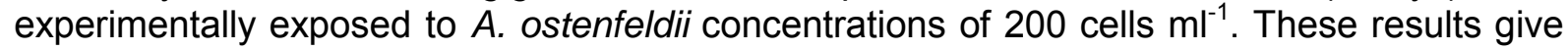
credit to the hypothesis that, in natural environment, oysters are able to accumulate these toxins from $A$. ostenfeldii cells. After 4 days of exposure, toxin profiles of $A$. ostenfeldii contaminated oysters, in both digestive gland and remaining tissues, were similar to that of A. ostenfeldii culture used in this experiment. These profiles were predominated by 13,19 didesMeC associated to smaller amounts of 13-desMeC and 13-desMeD. SPX E and F were not detected in any tissue indicating that biotransformation of spirolides did not occur in $C$. gigas during contamination. After 4 days exposure, most spirolides $(83 \%)$ were accumulated in digestive gland. Similarly, digestive glands generally contain $80 \%$ or more of Paralytic Shellfish Toxin (PST) body concentration (Bricelj and Shumway, 1998) in oysters. Similar results were observed for mussels (Bricelj et al., 1990), and scallops (Cembella et al., 1993; Choi et al., 2003) contaminated with PSP and for clams (Medhioub et al., 2010) contaminated with gymnodimines.

Various physico-chemical treatments including thermal and osmotic stress, electric shocks, $\mathrm{pH}$ decrease, ozonised seawater and chlorination have been tested to speed up detoxification of diarrheic and paralytic toxins accumulated by bivalves. All proposed methods were either too dangerous, too long, too expensive, or modified organoleptic characteristics of the product. Effective ways to detoxify shellfish contaminated by emergent toxins such as spirolides remain to be developed. No attempt has been made so far to detoxify SPX-contaminated shellfish. In this work, food supply was selected as a detoxification process to speed up spirolide elimination. After 7 days detoxification, total spirolide content in digestive gland was found to be lower in oysters fed on T.Iso than in unfed oysters. This is in good agreement with previous field and laboratory studies highlighting that availability and quantity of non toxic food was the most important factor regulating PSP and DSP detoxifications (Lassus et al., 1999 ; 2002 ; 2005; Guéguén et al., 2008 ; Haamer et al., 1990; Sampayo et al., 1990; Marcaillou-Le Baut et al., 1993; Bauder et al., 1996; Poletti et al., 1996; Blanco et al., 1999). Similarly, experiments on gymnodimine (another cyclic imine) detoxification by grooved carpet shell Ruditapes decussatus revealed that feeding clams with T.Iso accelerated gymnodimine detoxification (Medhioub et al., 2010). In the same way, Guéguen et al. (2008) showed that PST detoxification of Pacific oyster Crassostrea gigas fed on Skeletonema costatum diets optimised oyster detoxification in both digestive gland and remaining flesh. Also, phytoplankton abundance was associated with an increase of detoxification rate after DSP and PSP episodes (Sampayo et al., 1990 ; Blanco et al., 1997).

Conversely, detoxification of PST in purple clam, Hiatula rostrata, and lipophilic phycotoxin (okadaic acid) in mussels were unaffected by food availability (Chen and Chou, 2001 ; Svensson, 2003).

In Arcachon Bay, spirolide content in oyster (SPX-A and 13-desMeC) is generally reported as quite low, ranging from 0.6 to $5 \mu \mathrm{g} 13$-desMeC eq. $\mathrm{kg}^{-1}$ total tissues, and rapidly declining after disappearance of the causative dinoflagellate (Amzil et al., 2007). Similarly, spirolide content rapidly decreased during the detoxification period in our controlled conditions. The final amount of spirolides obtained after detoxification is in the same range as that found in the natural environment (approx. $6 \mu \mathrm{g}$ 13-desMeC eq. $\mathrm{kg}^{-1}$ total tissues). 
At the end of the detoxification period, total SPXs content was found in equal amounts in remaining tissues and in digestive gland. Slower detoxifications in remaining tissues (including gill, mantle, and foot) were in agreement with previous studies on other phycotoxins : gymnodimines-contaminated grooved carpet shell, Ruditapes decussatus (Linné) (Medhioub et al., 2010), PSP in king scallop Pecten maximus (Lassus et al., 1989) or DSP in mussels (Blanco et al., 1999). Rapid toxin loss during the first days of detoxification is generally coincident with the elimination of toxin-containing algae from digestive gland, whereas remaining toxins (resulting from microalgae digestion) were incorporated in the tissues.

During the detoxification period, we also found that individual spirolide analogues decreased at different rates. This may be due to the difference of structure of spirolide analogues and/or the difference of toxin affinity for the tissues. However, investigations with different toxin profiles are necessary to obtain a comprehensive picture of detoxification mechanisms of SPX-toxins at the analogue level in bivalves.

\subsection{Histology study}

In our experiment, oysters ingested $A$. ostenfeldii as revealed by cyst or intact cells presence in feces. However, as most $A$. ostenfeldii cells appeared as temporary cyst, it is suggested that oyster failed to fully digest all toxic algae. Presence of intact, toxic cells in digestive system of exposed bivalves has already been observed by Galimany et al., (2008a and c) and Hégaret et al. (2007, 2008a). Haberkorn et al. (2010) also reported intact vegetative cells and temporary cysts of $A$. minutum in oyster feces.

Oyster exposure to $A$. ostenfeldii at a concentration of 200 cell. $\mathrm{ml}^{-1}$ for 4 days resulted in non-specific biological responses. Thickness of digestive gland tubules decreased indicating that feeding upon $A$. ostenfeldii altered digestive processes.

An inflammatory response was also revealed by hemocyte infiltration and diapedesis. Hemocyte migration through diapedesis from the semi-open vascular system into the stomach and intestine, as seen in $A$. ostenfeldii exposed oysters, has been described as part of a defence mechanism in bivalves (Stauber, 1950). Digestive gland tissues showed hemocyte infiltration following toxic algae exposure in most oysters sampled on day 4 after exposure. This reaction supports the hypothesis that hemocytes migrate into lumina of digestive organs to remove $A$. ostenfeldii cells and/or to protect tissues from toxicity as it has been reported for different phycotoxin-contaminated bivalve species. Galimany et al. (2008a, b, c) described similar inflammatory responses (hemocyte infiltration and diapedesis) in blue mussels Mytilus edulis exposed to Alexandrium fundyense, Prorocentrum minimum and Karlodinium veneficum. Hemocyte infiltration and diapedesis were also observed into intestine and gonad follicles of Ruditapes philippinarum exposed to Prorocentrum minimum (Hégaret et al., 2009) and into the intestine and digestive gland of Crassostrea gigas exposed to A. minutum (Haberkorn et al., 2010). Estrada et al. (2007) observed hemocyte aggregation in the digestive gland, mantle, and gills of the scallop, Nodipecten subnodosus, exposed to the PST producer Gymnodinium catenatum.

All pathological conditions described here were almost only observed in oysters exposed to A. ostenfeldii. Nevertheless, few control oysters presented marginally affected digestive gland tubules. Some studies (Haberkorn et al., 2010; Galimany et al., 2008a) have also occasionally reported alteration such as inflammatory responses in control oysters. Such pathological conditions in control oysters can be found in the field and attributable to undefined environmental factors. 
Altogether, these results suggest that $A$. ostenfeldii could have an adverse effect on the digestive gland tubules, impairing the digestive and absorption processes and thus accelerating animal vulnerability under stress conditions, like for instance, exposure to pathogens.

This study also demonstrated that after 7 days detoxification of the experiment, pathologies induced by $A$. ostenfeldii exposure decreased while in the meantime percentage of active DG tubules increased in fed oysters. This suggests that feeding non-toxic algae contribute to speed up recovery after $A$. ostenfeldii exposure. However, the uncompleted recovery of unfed oysters revealed that repairing the digestive gland tubules request significant energy supply.

Our findings are in agreement with others studies. After exposure, to Gyrodinium aureolum, juvenile mussels fed on T.Iso during one week appeared to recover (Smolowitz and Shumway, 1997). Moreover, Galimany et al. (2008a) showed that feeding non-toxic algae Rhodomonas sp, all pathological conditions induced by $A$. fundyense exposure disappeared within a few days indicating a high and rapid capacity for recovery.

\section{Conclusion}

Detoxification of spirolides in digestive gland was higher in fed oysters than in non-fed oysters. SPX levels can be reduced within 7 days down to approximately $10 \%$ of the initial toxin content of laboratory-contaminated oysters. Taking into account that no regulatory limit has been established so far for spirolides, further experiments are needed to determine the level giving a negative DSP mouse bioassay.

Moreover, gut tubule thinning was the most obvious histopathological finding when oyster were exposed to $A$. ostenfeldii. We can hypothesize that this can be due to $A$. ostenfeldii haemolytic activity. However, recovery from exposure to toxic alga was rapid, although unfed oysters were unable to totally get back undamaged tubules. Feeding during the detoxification period accelerates both oyster recovery and detoxification processes. In the future, it would be worth testing longer and higher exposure to see whether effects increase with time and $A$. ostenfeldii density and whether oyster can still recover thereafter.

\section{Acknowlgements}

This study was supported by the Co-operation framework contract between French Research Institute for the Exploitation of the Sea (IFREMER), and the Tunisian National Institute of Marine Science and Technologies (INSTM). It was partially supported by the European University of Brittany (UEB). The authors are grateful to Véronique Savar, Florence Royer, Audrey Gueneugues, Nathalie Cochennec, Hélène Hégaret, Hansy Haberkorn and Philipp Hess for their friendly technical help.

\section{References}

Amzil, Z., Sibat, M., Royer, F., Masson, N., Abadie, E., 2007. Report on the first detection of Pectenotoxin-2, Spirolide-A and their derivatives in French shellfish. Mar. Drugs 5, 168-179.

Balech, E., Tangen, K. 1985. Morphology and taxonomy of toxic species in the tamarensis group (Dinophyceae): Alexandrium excavatum (Baarud) comb. nov. and Alexandrium ostenfeldii (Paulsen) comb. nov. Sarsia 70, 333-343. 
Bauder, A. G., Cembella, A.D., Quilliam, M.A., 1996. Dynamics of Diarrhetic Shellfis Toxins from the dinoflagellate Prorocentrum lima, in the bay scallop, Argopecten irradians. In: Yasumoto, T., Oshima, Y. Eds, Harmful and Toxic Algal Blooms, Elseiver, Amsterdam, pp. 433-436.

Blanco, J., Morono, A., Franco, J., Reyero, M.I., 1997. PSP detoxification kinetics in the mussel Mytilus galloprovincialis. one and two-compartement models and the effect of some environmental variables. Mar. Ecol., Prog. Ser. 176, 165-175.

Blanco, J., Fernandez, M.J., Miguez, A., Morono, A., 1999. Okadaic acid depuration in the mussel Mytilus galloprovincialis: one and two-compartement models and the effect of environmental conditions. Mar. Ecol., Prog. Ser. 176, 153-359.

Bravo, I., Garcés, E., Diogéne, J, Fraga, S., Sampedro, N., Figueroa, R.I., 2006. Resting cysts of the toxigenic dinoflagellate genus Alexandrium in recent sediments from the Western Mediterranean coast, including first description of cysts of $A$. kutnerae and $A$. peruvianum. Eur. J. Phycol. 41, 293-302.

Bricelj, V.M., Lee, J.H., Cembella, A.D., Anderson, D.M., 1990. Uptake kinetics of paralytic shellfish toxins from the dinoflagellate Alexandrium fundyense in the mussel Mytilus edulis. Mar. Ecol. Progr. Ser., 63, 177-188.

Bricelj, V.M., Shumway S.E., 1998. Paralytic shellfish toxins in bivalve mollusks: occurrence,transfer kinetics and biotransformation. Rev.Fisheries Science, 6 (4), 315383.

Chen, C. Y., Chou, H.N., 2001. Accumulation and depuration of paralytic shellfish poisoning toxins by urple clam Hiatula rostrata Lighttoot. Toxicon 39, 1029-1034.

Choi, M.C., Hsieh, D.P.H., Lam, P.K.S., Wang, W.X., 2003. Field depuration and biotransformation of paralytic shellfish toxins in scallop Chlamys nobilis and greenlipped mussel Perna viridis. Mar. Bio.143, 927-934.

Cembella, A.D., Shumway, S.E., Lewis, N.I., 1993. Anatomical distribution and spatiotemporal variation in paralytic shellfish toxin composition in two bivalve species from the Gulf of Maine. J Shellfish Res 12(2): 389-403.

Cembella, A.D., Bauder, A.G., Lewis, N.I., Quilliam, M.A., 2000a. Population dynamics and spirolide composition of the toxigenic dinoflagellate Alexandrium ostenfeldii in coastal embayments of Nova Scotia. In: Hallegraeff, G.M., Blackburn, S.I., Bolch, .J.S., Lewis, R.J. (Eds.), IX International Conference on Harmful Algal Blooms. Intergovernmental Oceanographic Commission, Hobart, Australia, pp. 173-176.

Cembella, A.D., Lewis, N.I., Quilliam, M.A., 2000b. The marine dinoflagellate Alexandrium ostenfeldii (Dinophyceae) as the causative organism of spirolide shellfish toxins. Phycologia 39, 67-74.

Cembella, A.D., Bauder, A.G., Lewis, N.I., Quilliam, M.A., 2001. Association of the gonyaulacoid dinoflagellate Alexandrium ostenfeldii with spirolide toxins in size fractionated plankton. J. Plank. Res. 23, 1413-1419.

Estrada, N., de Jesus Romero, M., Campa-Cordova, A., Luna, A., Ascencio, F., 2007. Effects of the toxic dinoflagellate, Gymnodinium catenatum on hydrolytic and antioxidant enzymes, in tissues of the giant lions-paw scallop Nodipecten subnodosus. Comp. Biochem. Physiol. C Pharmacol. Toxicol. Endocrinol. 146, 502-510.

Fraga, S., Sánchez, F., 1985. Toxic and potentially toxic dinoflagellates found in Galacian Rias (NW Spain). In: Anderson, D.M., White, A., Baden, D. (Eds.), Toxic Dinoflagellates. Elsevier Science Publishing Co., Inc., New York, pp. 51-54.

Galimany, E., Sunila, I., Hégaret, H., Ramón, M., Wikfors, G.H., 2008a. Experimental exposure of the blue mussel (Mytilus edulis, L.) to the toxic dinoflagellate Alexandrium fundyense: Histopathology, immune responses, and recovery. Harmful Algae 7, 702711.

Galimany, E., Sunila, I., Hégaret, H., Ramón, M., Wikfors, G.H., 2008b. Pathology and immune response of the blue mussel (Mytilus edulis L.) after an exposure to the harmful dinoflagellate Prorocentrum minimum. Harmful Algae 7, 630-638. 
Galimany, E., Place, A.R., Ramon, M., Jutson, M., Pipe, R.K., 2008c. The effects of feeding Karlodinium veneficum (PLY \# 103; Gymnodinium veneficum Ballantine) to the blue mussel Mytilus edulis. Harmful Algae 7, 91-98.

Guéguen, M., Bardouil, M., Baron, R., Lassus, P., Truquet, P., Massardier, J.,Amzil, Z., 2008 Detoxification of Pacific oyster Crassostrea gigas fed on dietsof Skeletonema costatum with and without silt, following PSPcontamination by Alexandrium minutum. Aquat. Living Resour. 21, 13-20.

Guillard, R.R.L., Hargraves, P.E., 1993. Stichochrysis immobilis is a diatom, not a chrysophyte. Phycologia 32, 234-236.

Gribble, K.E., Keafer, B.A., Quilliam, M.A., Cembella, A.D., Kulis, D.M., Manahan, A., Anderson, D.M. 2005. Distribution and toxicity of Alexandrium ostenfeldii (Dinophyceae) in the Gulf of Maine, USA. Deep-Sea Res. II 52, 2745-2763.

Haamer, J., Andersson, P.O., Lange, S., Li,X,P., Edebo, L., 1990. Effects of transplantation and reimmersion of mussels Mytilus edulis L. on their contents of okadaic acid. $\mathrm{J}$. Shellfish Res. 9 (1), 109-112.

Haberkorn, H., Lambert, C., Le Göıc, N., Moal, J., Suquet, M., Gu'eguen, M., Sunila, I., Soudant, P. 2010. Effects of Alexandrium minutum exposure on nutrition-related processes and reproductive output in oysters Crassostrea gigas, Harmful Algae 9 : 427-439.

Hansen, P.J., Cembella, A.D., Moestrup, Ø., 1992. The marine dinoflagellate Alexandrium ostenfeldii: paralytic shellfish toxin concentration, composition, and toxicity to a tintinnid ciliate. J. Phycol. 28, 597-603.

Hégaret, H., Wikfors, G., Soudant, P., Lambert, C., Shumway, S., Bérard, J., Lassus, P., 2007.Toxic dinoflagellates (Alexandrium fundyense and $A$. catenella) have minimal apparent effects on oyster hemocytes. Mar. Biol. 152, 441-447.

Hégaret, H., Shumway, S.E., Wikfors, G.H., Pate, S., Burkholder, J.M., 2008a. Potential transport of harmful algae via relocation of bivalve mollusks. Mar. Ecol. Prog. Ser.361, 169-179.

Hégaret, H., da Silva, P., Sunila, I., Dixon, M.S., Alix, J., Shumway, S.E., Wikfors, G.H., Soudant, P., 2009. Perkinsosis in the Manila clam Ruditapes philippinarum affects responses to the harmful-alga, Prorocentrum minimum. J. Exp. Mar. Biol. Ecol. 371, 112-120.

Hu, T., Curtis, J.M., Oshima, Y., Quilliam, M.A., Walter, J.A., Watson-Wright, W., Wright, J.L.C., 1995. Spirolides B and D, two novel macrocycles isolated from the digestive glands of shellfish. Journal of the Chemical Society, Chemical Communications, 2159-2161.

Hu T, Burton IW, Cembella AD, Curtis JM, Quilliam MA, Walter JA, Wright JL. 2001. Characterization of spirolides a, c, and 13-desmethyl c, new marine toxins isolated from toxic plankton and contaminated shellfish. J Nat Prod 64:308-312.

Jacobson, D.M., Anderson, D.M., 1996. Widespread phagocytosis of ciliates and otherprotists by marine mixotrophic and heterotrophic thecate dinoflagellates. J. Phycol. 32,279-285.

John, U., Fensome, R.A., Medlin, L.K. 2003a. The application of a molecular clock based on molecular sequences and the fossil record to explain biogeographic distributions within the Alexandrium tamarense "species complex" (Dinophyceae). Mol. Biol. Evol.20, 1015-1027.

John, U., Cembella, A., Hummert, C., Elebrachter, M., Groben, R., Medlin, L., 2003b. Discrimination of the toxigenic dinoflagellates Alexandrium tamarense and A.ostenfeldii in co-occurring natural populations from Scottish coastal waters. Eur. J.Phycol. 38, 25-40.

Lassus, P., Fremy, J.M., Ledoux, M., Bardouil, M., Bochec, M., 1989. Patterns of experimental contamination by Protogonyaulax tamarensis in some French commercial shellfish. Toxicon 12: 1313-1321.

Lassus, P., Bardouil, M., Beliaeff, B., Masselin, P., Naviner, M., Truquet, P., 1999. Effect of a continuous supply of the toxic dinoflagellate Alexandrium minutum Halim on the 
feeding behavior of the Pacific oyster (Crassostrea gigas Thunberg). J. Shellfish Res. 18, 211-216.

Lassus P., Bardouil, M., Beliaeff, B., Bougrier, S., Gubbins, M., Masselin, P., Mornet, F., Thébaud, O., Truquet, P., 2002. Coquillage contaminés par des phycotoxines paralysantes: vers une procédure de détoxification

Lassus, P., Bardouil, M., Baron, R., Berard, J.B., Masselin, P., Truquet, P., Pitrat, J.P., 2005. Improving detoxification efficiency of PSP contaminated oysters (Crassostrea gigas Thunberg). Aquaculture Europe:3-6.

MacKenzie, L., White, D., Adamson, J., 1996a. Temporal variatio and tissue localisation of paralytic shellfish toxins in the New Zealand Tuatua (surfclam), Paphies subtriangulata. J. Shell. Res. 15, 735-740.

MacKenzie, L., White, D., Oshima, Y., Kapa, J., 1996b. The resting cyst and toxicity of Alexandrium ostenfeldii (Dinophyceae) in New Zealand. Phycologia 35, 148-155.

MacKenzie, L., Adamson, J., White, D., Todd, K., 1996c. Alexandrium catenella and PSPtoxin contamination of shellfish in the Bay of Plenty: progress to date on an investigation of the April/May 1996 bloom. In: Proceedings of the Marine Biotoxin Science Workshop No. 6, Wellington, 18 October 1996.

MacKinnon, S.L., Cembella, A.D., Quilliam, M.A., LeBlanc, P., Lewis, N.I., Hardstaff, W.R., Burton, I.W., Walter, J.A., 2004. The characterization of two new spirolides isolated from Danish strains of the toxigenic dinoflagellate Alexandrium ostenfeldii. In: Steidinger, K.A., Landsberg, J.H., Tomas, C.R., Vargo, G.A. (Eds.), Harmful Algae 2002. Florida Fish and Wildlife Conservation Commission, Florida Institute of Oceanography, and Intergovernmental Oceanographic Commission of UNESCO, St.Petersburg, FL, USA, St. Pete Beach, FL, pp. 186-188.

MacKinnon SL, Walter JA, Quilliam MA, Cembella AD, Leblanc P, Burton IW, Hardstaff WR, Lewis NI. 2006. Spirolides isolated from Danish strains of the toxigenic dinoflagellate Alexandrium ostenfeldii.J Nat Prod 69:983-987.

Marcaillou-Le Baut, C., Bardin, B., Bardouil, M., Bohec, M., Le Dean, L., Masselin, P., Truquet, P., 1993. DSP depuration rates mussels reared in a laboratory and an aquaculture pond. In: Smayda TJ, Shimizu Y (eds), toxic phytoplankton blooms at the sea. Elsevier, Amsterdam, p 531-535.

Medhioub W., Guéguen M., Lassus P., Bardouil M., Truquet P., Sibat M., Medhioub N., Soudant P., Kraiem M. \& Amzil Z. 2010.Detoxification enhancement in the gymnodimine-contaminated grooved carpetshell, Ruditapes decussatus (Linné).Harmful Algae 9 : 200-207

Moestrup, $\varnothing$., Hansen, P.J., 1988. On the occurrence of the potentially toxic dinoflagellates Alexandrium tamarense (Gonyaulax excavata) and $A$. ostenfeldii in Danish and Faroese waters. Ophelia 28, 195-213.

Munday, M. 2008. Toxicology of cyclic imines: gymnodimine, spirolides, pinnatoxins, pteriatoxins, prorocentrolide, spiro-prorocentrimine and symbioimines,,in: L.M. Botana (Ed.), Seafood and Freshwater Toxins: Pharmacology, Physiology and Detection, 2nd edition, CRC Press, New York, p. 581.

Østergaard-Jensen, M., Moestrup, Ø. 1997. Autecology of the toxic dinoflagellate Alexandrium ostenfeldii: life history and growth at different temperatures and salinities. Eur.J. Phycol. 31, 9-18.

Poletti, R., Viviani, R., Cassadei, C., Lucentini, L., Funari, E., draisci, R., 1996. depuration dynamics of mussels naturally contaminated with diarrhetic toxins relocated to a basin of the Adriatic sea In : Yasumuto, T., Oshima, Y., Fukuyo, Y Eds Harmful and Toxic Algal Blooms. Intergovenmental Oceanographic Commision of UNESCO, pp. 429432.

Report of the Joint FAO/IOC/WHO ad hoc Expert Consultation on Biotoxins in Bivalve Molluscs Oslo, Norway, 26-30 September 2004. p3.

Richard, D., Arsenault, E., Cembella, A., Quilliam, M.A., 2000. Investigations into the toxicology and pharmacology of spirolides, a novel group of shellfish toxins. In: 
Hallegraeff, G.M., Blackburn, S.I., Bolch, C.J.S., Lewis, R.J. (Eds.), IX International Conference on Harmful Algal Blooms. Intergovernmental Oceanographic Commission, Hobart, Australia, pp. 383-386.

Sampayo, M.A., Alvito, P., Franca, S., Sousa, I., 1990. Dinophysis spp, toxicity and relation to accompanying species. In: Granéli, E., Sundstrom, B., Edler, L., Anderson, D.M.M Eds, Toxic Marine Phytoplankton. Elseiver, New York, pp. 215-220.

Shaw, B.L., Battle, H.I., 1957. The gross and microscopic anatomy of the digestive tract of the oyster Crassostrea virginica (Gmelin). Can. J. Zool. 35, 325-347.

Sleno L, Windust AJ, Volmer DA. 2004. Structural study of spirolide marine toxins by mass spectrometry. Part I. Fragmentation pathways of 13-desmethyl spirolide $\mathrm{C}$ by collision induced dissociation and infrared multiphoton dissociation mass spectrometry. Anal Bioanal Chem. 378:969-976.

Smolowitz, R., Shumway, E.S., 1997. Possible cytotoxic effects of the dinoflagellate, Gyrodinium aureolum, on juvenile bivalve molluscs. Aquaculture International 5, 291300.

Stauber, L.A., 1950. The fate of india ink injected intracardially into the oyster, Ostrea virginica Gmelin, Biol. Bull. 98 , pp. 227-241.

Svensson, S., 2003. Depuration of Okadaic acid (Diarrhetic Shellfish Toxin) in mussels, Mytilus edulis (Linnaeus), feeding on different quantities of nontoxic algae. Aquaculture 218, 277-291.

Tillmann, U., John, U., Cembella, A.D., 2007. On the allelochemical potency of the marine dinoflagellate Alexandrium ostenfeldii against heterotrophic and autotrophic protists. J. Plankton Res. 29, 527-543.

\section{Tables}

Table $1: \mathrm{m} / \mathrm{z}$ transition conditions for spirolides. $M / \mathrm{z}$ (mass to charge ratio).

\begin{tabular}{cl}
\hline Spirolides (SPX) detected by LC-MS/MS & Transitions $\mathbf{~ m / \mathbf { z }}$ \\
\hline D & $708.5>690.5 / 164$ \\
13-desMeC & $692.7>444.3 / 164.2$ \\
13,19-didesMeC & $678.5>660.4 / 642.4 / 624.4 / 430.5$ \\
13-desMeD & $694.5>444.3 / 164.5$ \\
\hline
\end{tabular}


Table 2: Spirolide concentrations in A. ostenfeldii culture (strain CCMP1773).

\begin{tabular}{cc}
\hline Spirolides (SPX) & Quantity \\
\hline D & (pg eq 13-desMeC cell $\left.{ }^{-1}\right)$ \\
13-desMeC & Trace \\
13,19-didesMeC & 0.43 \\
13-desMeD & 1.4 \\
\end{tabular}

Table 3: Limits of detection and quantification of each lipophilic toxin.

\begin{tabular}{|c|c|c|}
\hline & \multicolumn{2}{|c|}{ Expressed as $\mu \mathrm{g} / \mathrm{kg}$ of total tissues } \\
\hline & Limit of detection (LOD) & Limit of quantification (LOQ) \\
\hline Okadaic acid (OA) & 5 & 10 \\
\hline Pectenotoxins (PTXs) & 1.5 & 3 \\
\hline Azaspiracides (AZAs) & 1 & 2 \\
\hline Yessotoxines (YTXs) & 5 & 10 \\
\hline Spirolides (SPXs) & 0.5 & 1.5 \\
\hline Gymnodimines (GYMs) & 1.5 & 3 \\
\hline
\end{tabular}


Table 4. Spirolides concentrations in digestive gland and remaining tissues ( $\mu \mathrm{g}$ SPX eq 13desMeC $\mathrm{kg}^{-1}$ ) during the detoxification period.

\begin{tabular}{|c|c|c|c|c|}
\hline Time & Treatments & 13,19-didesMeC & 13-desMeC & 13-desMeD \\
\hline 0 & - & $412.5 \pm 9.1(100 \%)$ & $\begin{array}{c}128.9 \pm 1.2 \\
(100 \%)\end{array}$ & $\begin{array}{c}26.1 \pm 1.7 \\
(100 \%)\end{array}$ \\
\hline 1 & $\begin{array}{l}\text { Without feeding } \\
\text { With algal food }\end{array}$ & $\begin{array}{c}353.1 \pm 39.6 \\
(85.6 \%) \\
220.6 \pm 21(53.5 \%)\end{array}$ & $\begin{array}{c}88.4 \pm 10.5 \\
(68.6 \%) \\
64.3 \pm 10.6 \\
(49.9 \%)\end{array}$ & $\begin{array}{c}25.8 \pm 1.7 \\
(98.8 \%) \\
21.3 \pm 1.2 \\
(81.6 \%)\end{array}$ \\
\hline 4 & $\begin{array}{l}\text { Without feeding } \\
\text { With algal food }\end{array}$ & $\begin{array}{l}73.6 \pm 6.1(17.9 \%) \\
56.8 \pm 3.5(13.8 \%)\end{array}$ & $\begin{array}{l}27.4 \pm 1.5(21.2 \%) \\
21.4 \pm 1.2(16.6 \%)\end{array}$ & $\begin{array}{c}10.7 \pm 0.1(41 \%) \\
8.7 \pm 1.3(33.3 \%)\end{array}$ \\
\hline 7 & $\begin{array}{l}\text { Without feeding } \\
\text { With algal food }\end{array}$ & $\begin{array}{c}80.6 \pm 2.9(19.5 \%) \\
30.9 \pm 0.7(7.5 \%)\end{array}$ & $\begin{array}{c}25.2 \pm 2.8(19.8 \%) \\
10.2 \pm 0.2(7.9 \%) \\
\end{array}$ & $\begin{array}{l}8.0 \pm 0.1(30.6 \%) \\
8.0 \pm 0.1(30.6 \%)\end{array}$ \\
\hline 0 & - & $76.1 \pm 3(100 \%)$ & $29.0 \pm 1.7(100 \%)$ & $\begin{array}{c}11.0 \pm 0.4 \\
(100 \%) \\
9.6 \pm 0.1\end{array}$ \\
\hline 1 & $\begin{array}{l}\text { Without feeding } \\
\text { With algal food }\end{array}$ & $\begin{array}{c}37.4 \pm 1.5(49.1 \%) \\
39.7 \pm 1(52.2 \%)\end{array}$ & $\begin{array}{c}20.3 \pm 1.9(70 \%) \\
21.1 \pm 0.5(72.7 \%)\end{array}$ & $\begin{array}{l}(87.27 \%) \\
10.0 \pm 0.3 \\
(90.9 \%)\end{array}$ \\
\hline 4 & $\begin{array}{l}\text { Without feeding } \\
\text { With algal food }\end{array}$ & $\begin{array}{c}21.7 \pm 0.2(28.5 \%) \\
22.1 \pm 0.2(29 \%)\end{array}$ & $\begin{array}{l}13.8 \pm 0.6(47.6 \%) \\
14.9 \pm 0.2(51.4 \%)\end{array}$ & $\begin{array}{l}9.0 \pm 0.1(81.8 \%) \\
8.9 \pm 0.1(80.9 \%)\end{array}$ \\
\hline & Without feeding & $17.5 \pm 0.4(23 \%)$ & $12.8 \pm 0.5(44.1 \%)$ & $8.7 \pm 0.1(79.1 \%)$ \\
\hline 7 & With algal food & $21.0 \pm 0.7(27.6 \%)$ & $13.4 \pm 0.7(46.2 \%)$ & $9.2 \pm 0.1(83.6 \%)$ \\
\hline
\end{tabular}

Table 5. Intensity of pathological effects of $A$. ostenfeldii before and after 4 days exposure and 7 days detoxifcation in oyster digestive gland and gills. Results are expressed as mean of stage intensity \pm confidence interval $(n=10)$, with stage $0=$ absence or very light, $1=$ moderate and stage 2 = heavy. Significant differences between the two treatments with or without feeding are indicated by* when $\mathrm{p}<0.05$.

Organ

Variable

Intestine

Digestive gland

\section{Before exposure}

0
After 4

days exposure

\section{After 7 days} detoxification

Without feeding

With algal food

Chi-square test

NS

NS

NS

$\begin{array}{llll}0.2 \pm 0.4 & 1.1 \pm 0.6 & 0.7 \pm 0.7 & 0.6 \pm 0.7\end{array}$

$0.3 \pm 0.7$

NS

Hemocytes in diapedesis in intestinal groove

Hemocytes in diapedesis in

$0.3 \pm 0.7$

$0.6 \pm 0.7$

$0.5 \pm 0.7$

$0.4 \pm 0.7$

NS digestive tubules 


\section{Figures}

Figure 1. Toxin profiles (expressed as \%) of (a) Alexandrium ostenfeldii at days $1 \& 3$ of the experiment and (b) of digestive gland (DG) and remaining tissues (RM) of oysters after 4 day exposure to $A$. ostenfeldii.

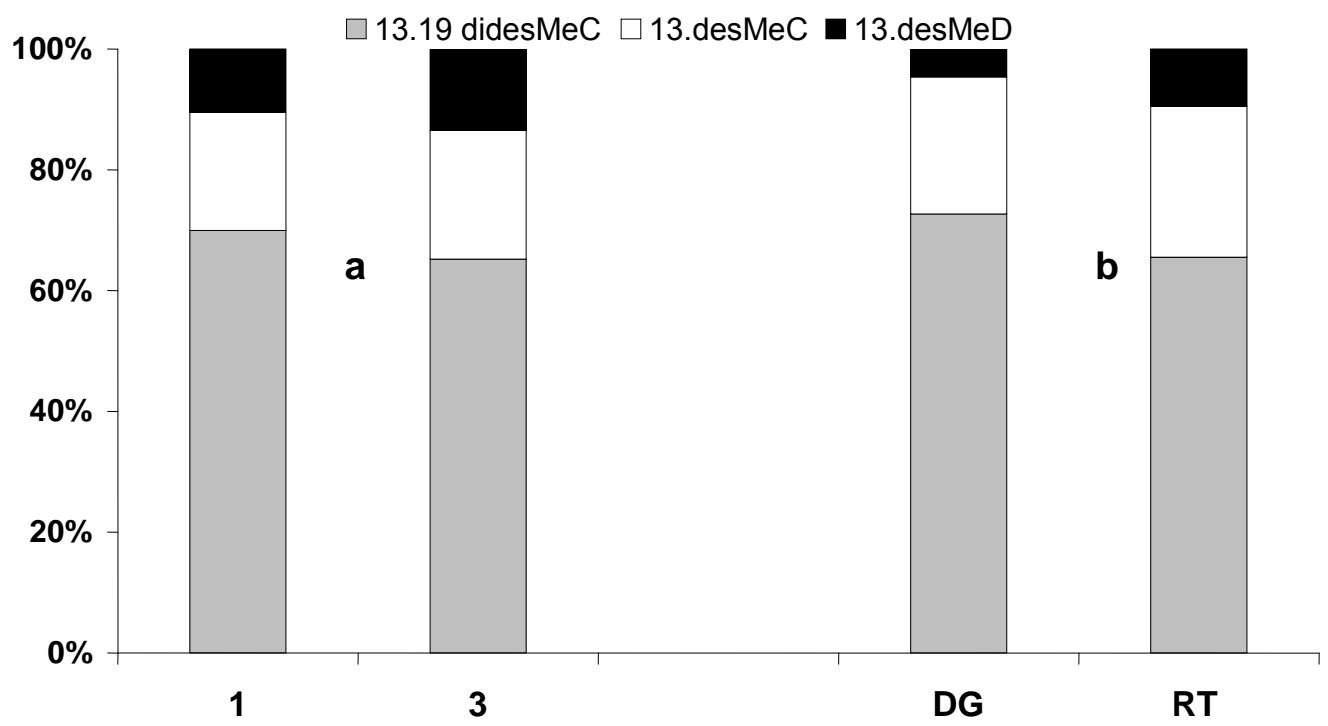

Figure 2. Detoxification of total SPXs in (DG) digestive gland (a) and (RT) remaining tissues (b) from contaminated oysters (Mean and S.D. of 3 analysis: spirolide analytical triplicate).

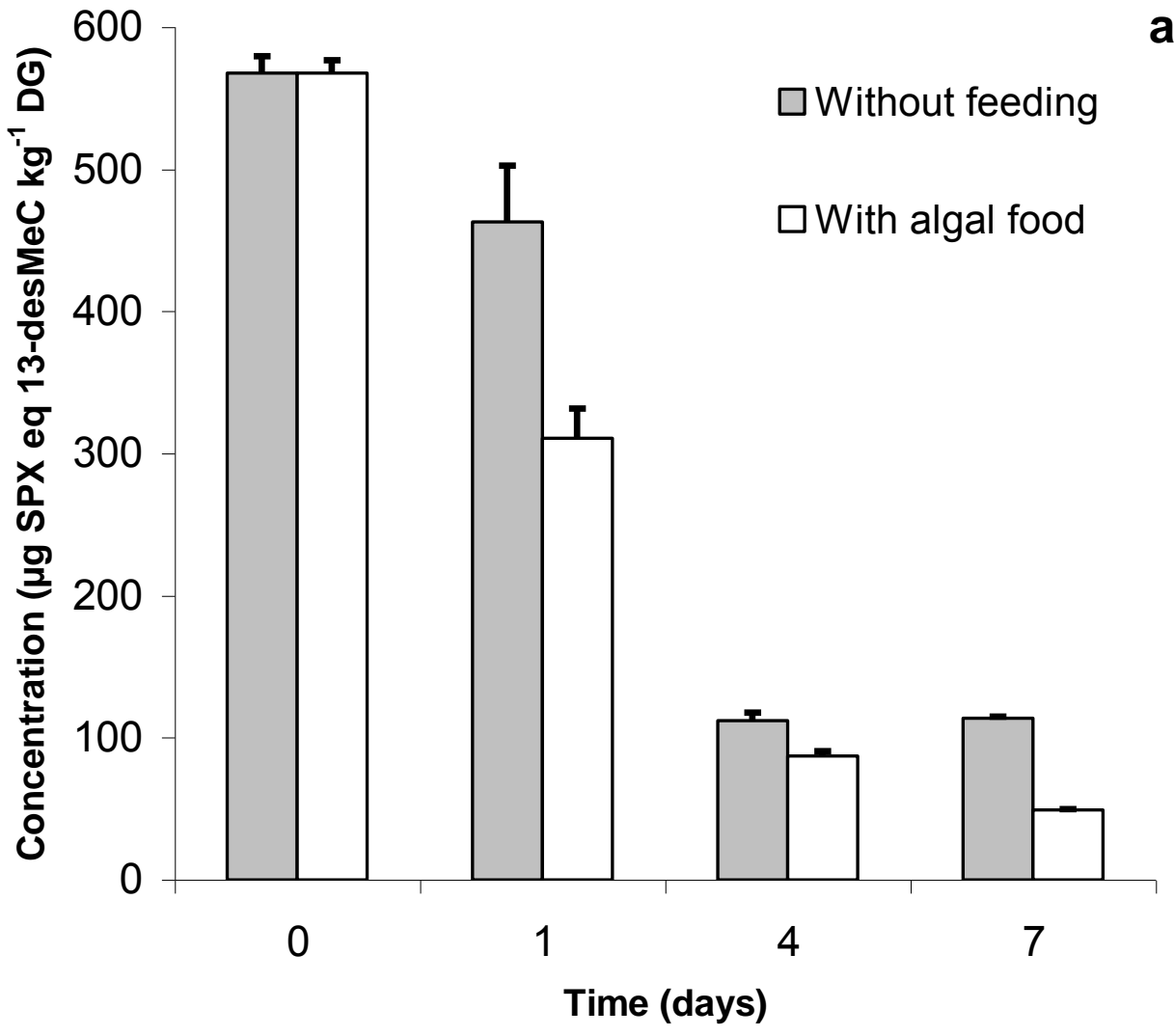




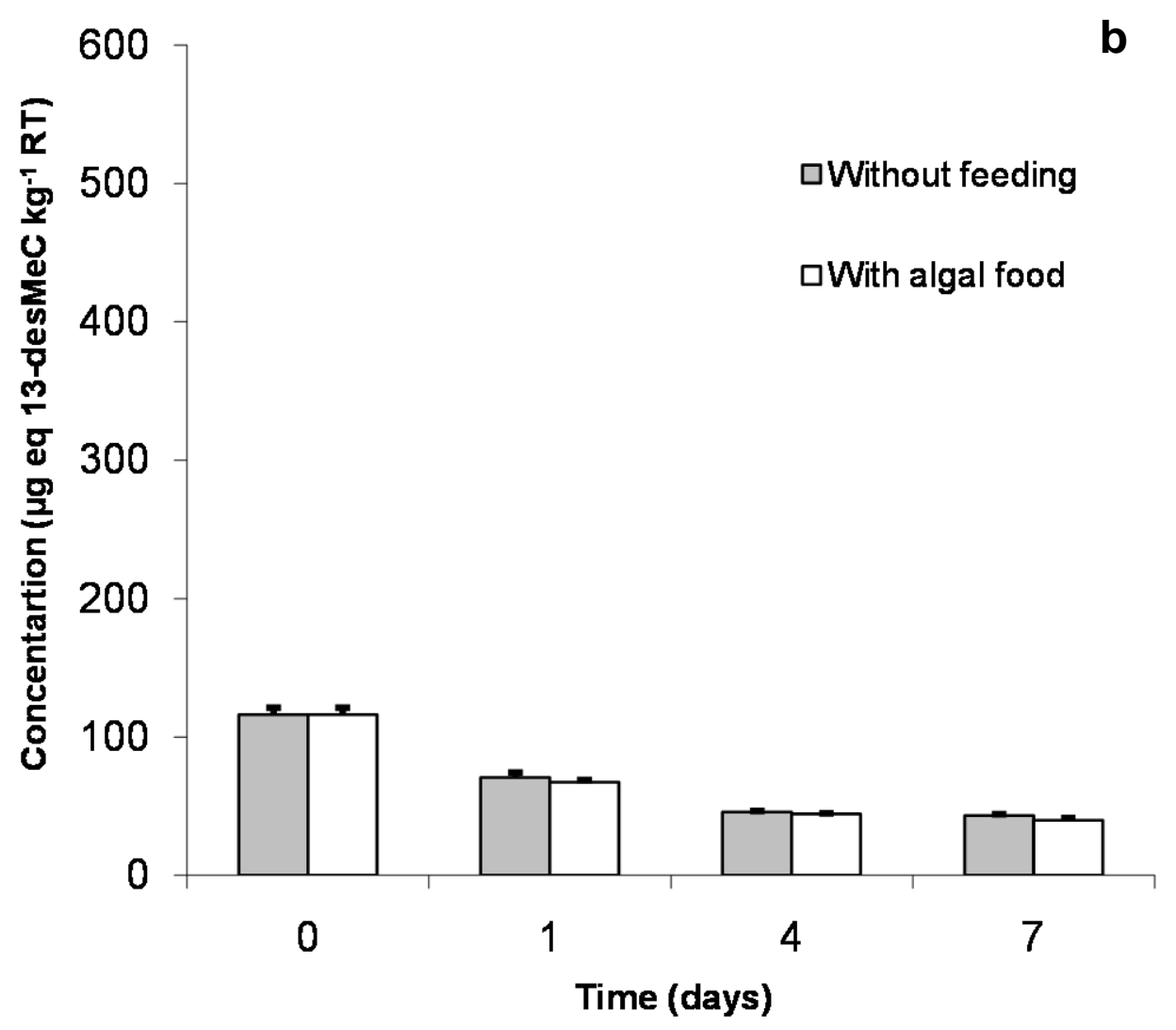


Figure 3. Percentage of active digestive gland tubules during the experiment. From left to right: reference before exposure to $A$. ostenfeldii; after contamination with $A$. ostenfeldii and finally after 7 days of detoxification (gray bar referring to fed oyster and white bar referring to unfed oyster). Results are expressed as mean percentages of active digestive gland tubules \pm confidence limits $(n=10)$. ${ }^{*}$ significant differences between treatment for $p<0.05$

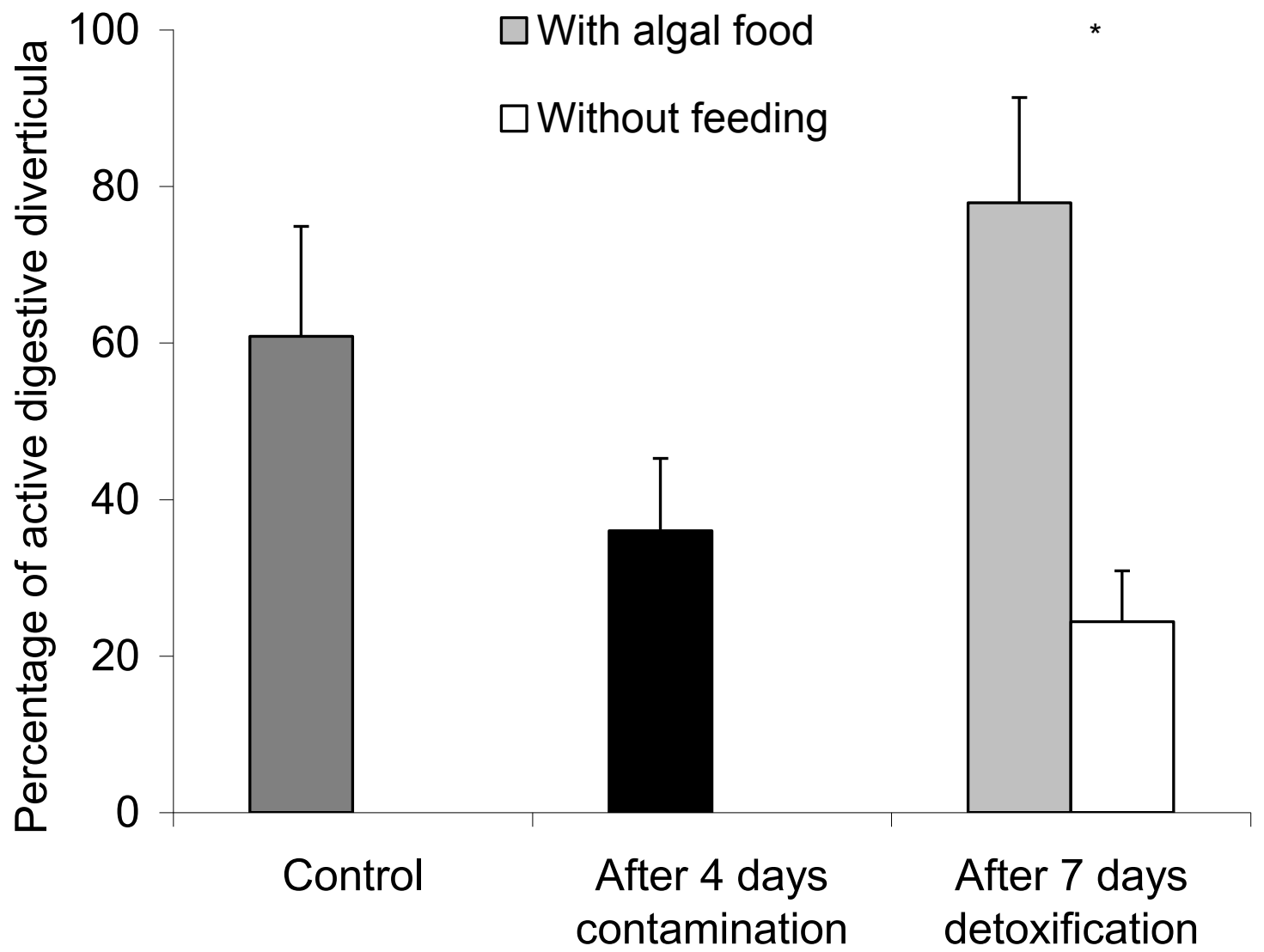


Figure 4. Inflammatory response in the intestine of $A$. ostenfeldii-exposed oysters. Aggregation of hemocytes in the connective tissue surrounding the intestine and hemocytes in diapedesis through the intestine epithelium. Hematoxylin-eosin stained paraffin sections (5 $\mu \mathrm{m})$. (Ao) A. ostenfeldii in intestine (I) of $C$. gigas, $(\mathrm{H})$ surrounding hemocytes and $(\mathrm{Hd})$ hemocytes in diapedesis.

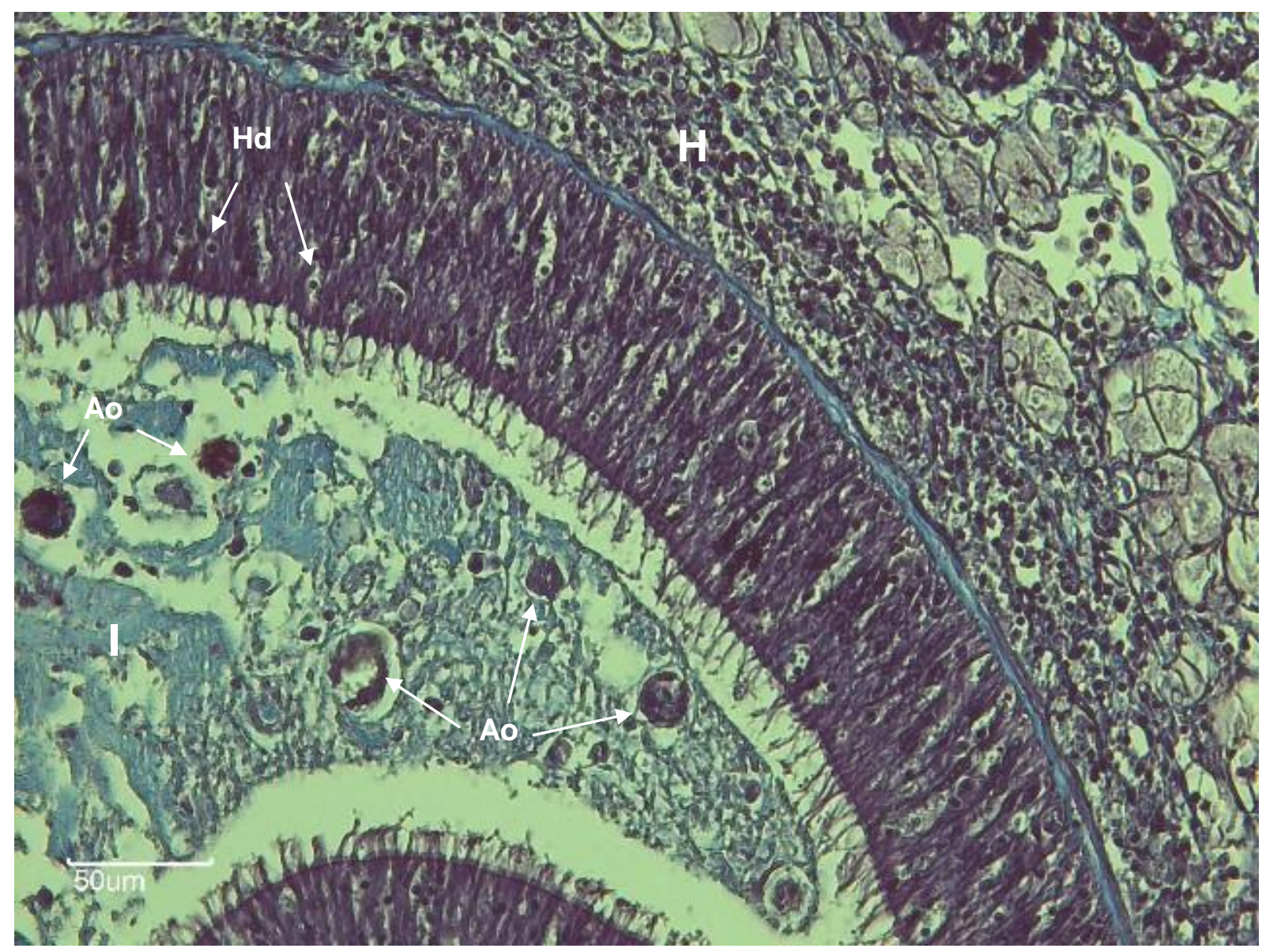


Figure 5. Intact cells of Alexandrium ostenfeldii found in faeces from Crassostrea gigas during exposure (scale bar $=20 \mu \mathrm{m})$.

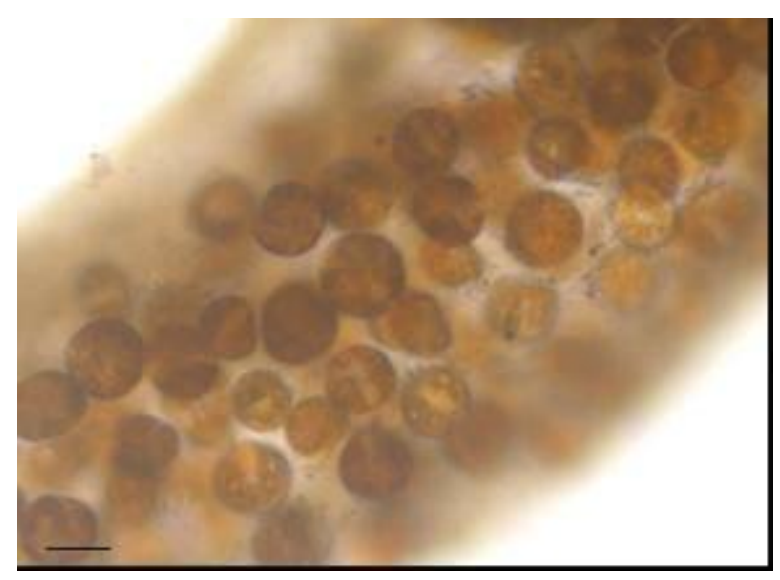

